\title{
Communicative Behaviors of Filipino Seafarers: Toward the Development of a Globally Responsive Maritime English Course
}

\author{
By Caroline Dacwag*
}

\begin{abstract}
Maritime English creatively and uniquely demonstrates communicative behaviors that enable seafarer interlocutors to successfully and effectively give and receive vital information to ensure safety of life, the vessel and the environment. As a training ground for future maritime officers, maritime institutions are expected to deliver courses that meet the need of the maritime industry, including the language of the sea. In response to the changes in curriculum and the challenges of communications at sea, this study aims to describe the communicative behaviors of Filipinos onboard international merchant marine vessels. Specifically, it sought to answer the following questions: a. How may the behavior of Filipino seafarers be described along the following areas- verbal communication, non-verbal communication, cross-cultural communication, listening, and creating healthy communicative relationships?; $b$. Is there a significant difference in the behaviors of Filipino seafarers when they are grouped according to their field of work?; $c$. In what areas of communicative behavior do the Filipinos need to improve?; . What Maritime English course can be developed to address the areas that need improvement and to ensure global communicative competence of Filipino maritime students? One hundred eighty-seven (187) students of the Maritime Academy of Asia and the Pacific (MAAP) who have gone onboard for their shipboard training and 127 active Filipino seafarers were the participants of the study. Results show that: a. Filipino seafarers practice desirable communicative behaviors often; $b$. the deck and the engine group significantly differ in their communicative practices; c. the engine group needs to practice using English and focus on the situation at hand more often. These findings were used as one of the bases of the design and development of a responsive maritime English course.
\end{abstract}

Keywords: communicative behaviors, Filipino seafarers, globally responsive course, Maritime English, maritime education and training (MET) institutions.

\section{Introduction}

Communicative behavior is a "range of standards and traditions of communication of people" (Kabylbekova, Ashirimbetova \& Akhmetzhanova, 2014, p. 29). It includes acts that interactants do with their words and gestures like listening, clarifying, deliberating and discussing, among other things (University of Pittsburgh, 2007). The standards vary from culture to culture or from nation to another. Thus, it is imperative that interlocutors become culturally aware and sensitive in order to avoid miscommunications related to culture insensitivity.

* English Faculty and Assistant Research Coordinator, Maritime Academy of Asia and the Pacific, Philippines. 
Kotorova (2014) adds that interlocutors as the representatives of linguosocioculture determine the norms of communication. Since they come from different backgrounds, they bear and exhibit "peculiarities". These peculiarities are defined by socio-pragmatic, cultural, situational and linguistic factors (p. 186).

In the maritime context, the communication space and the interactants are unique. Given this nature, competence is required so that communication difficulties may be avoided. Seafarers who come from different parts of the world carry with them their unique cultures and their language. The latter, having resulted in serious accidents, gave birth to the creation of the Standard Marine Communication Phrases (SMCP).

Since its adoption in 2000, SMCP has helped solve the problem of communication barriers and issues on board. With the use of simplified and codified English between and among seafarers, it became relatively easier to convey vital information that affects ship operations. However, accidents still occur due to human factors, specifically communication breakdowns (Nakazawa, 2014; Ion, 2012; Popescu \& Varsami, 2010; Pyne \& Koester, 2005). These communication breakdowns do not only happen between seafarers but also in the other fields, like caregivers and their patients, who have different languages (Pressman, Pietzyk, \& Schneider, 2011).

Maritime Education and Training (MET) institutions play a vital role in solving the issue on communication breakdowns and barriers on board merchant vessels (Baylon \& Santos, 2011; Rashed \& Kamal, 2010; Horck, 2008). Karthik (2014) specifically focused on the need to develop among maritime students/ trainees intercultural communicative competence. MET institutes prepare and train future seafarers for the kind of life at sea; therefore, these academic institutions have the responsibility of ensuring the maritime students' competence in all aspects- technical, social, psychological and communicative, among others.

The Maritime Academy of Asia and the Pacific (MAAP) as one responsive and quality maritime education institution meets the challenge of providing competent future seafarers through updated and regularly evaluated course specifications and manuals. Under the regulatory and monitoring body of the Commission on Higher Education (CHED), MAAP has to follow the curriculum set, including the courses that have to be delivered. However, the CHED mandate does not specify the topics for each course. It is in the school to decide which topics are to be included. It is within this premise that this study is conducted, to have at least a basis in determining the topics to be included in one of the newly required course, Speech Communication with SMCP.

Miscommunication is inevitable, but it is not caused solely by misunderstanding other speakers because of their speech behavior; miscommunication is also caused by cultural differences. The more one knows about other people's culture, the better the communication. This and when one communicates, he or she also shares his/her culture (Guessabi, 2016). With the ship being manned by seafarers from different cultural backgrounds, it is imperative that each one of them become aware of each other's culture to avoid conflicts that may lead to accidents.

The Standards of Training, Certification and Watchkeeping of Seafarers 
(STCW) including the Manila Amendments (2011) necessitates that seafarers have competence in speaking and writing in English, the language of the sea. However, the specifics on how to achieve this competence are not given in the tables of specifications of minimum standards. It is up to the concerned institution to design its curriculum to meet this requirement.

Parsons, Potoker, Progoulaki, and Batiduan (2011) noted that maritime graduates are not very skilled in communication, among other things. It was also emphasized in this assembly that there is a need for maritime students and active seafarers to acquire cross-cultural competence for them to have crosscultural awareness and be able to adapt to the multi-lingual crew on board. Also, it was found out that maritime institutions do not offer courses that address this issue as this is not yet mandated by the International Maritime Organization (IMO) or the STCW Code.

Badawi and Halawa (2003) stressed the need for education programs to address "the problem of communication between multilingual and multicultural ship crew members" and study "the problems that may arise due to cross cultural differences". They specifically covered cultural barriers like speed and rhythm of communication, tone and volume of voice, pausing in speech, gestures and eye contact, among others. Furthermore, Rehman (2007) recommended in his dissertation that IMO develop model courses on communication skills and cultural awareness and that STCW specifically include this as one of the required competencies.

Though Tran (2007) focused on cultural sensitivity, he also expressed the need for maritime institutions to include this as a course in their curriculum as this will also address the problem on miscommunications or misunderstandings among the multilingual crew on board.

The aforementioned papers have expressed a common concern, that is, the need to explicitly include cultural awareness in the honing of communication skills of seafarers. The use of SMCP, though very helpful, does not totally address the problem of communication breakdowns between and among crew members of different nationalities or cultural backgrounds. Also, as used in spoken communication, other factors like gestures, the tone of voice, facial expression and other non-verbal forms of communication seem to be excluded in the trainings of future seafarers.

As an attempt to address the aforementioned concerns, the following objectives were formulated to guide the conduct of this study: describe the behavior of Filipino seafarers along verbal communication, non-verbal communication, cross-cultural communication, listening, and creating healthy communicative relationships; determine if there is a significant difference in the behaviors of Filipino seafarers when they are grouped according to their field of work; identify areas of communicative behavior that need improvement; and develop a course manual that addresses the areas that need improvement and ensure global communicative competence of Filipino maritime students. 


\section{Research Design}

\section{Methodology}

This study employed the descriptive method as it aimed to describe a situational area of seafaring, which is communication. The researcher did not control the communicative situation; she just presented a picture of it based on the impression of the respondents, the seafarers themselves. In addition, it also made use of the common descriptive research tool, a questionnaire, in gathering data.

\section{Data Gathering Tool}

To satisfy the objectives of the study, a research-designed questionnaire that is based on the book of Fujishin (2009) was used. The data-gathering instrument is composed of five main parts addressing the variables under the first problem. These five main parts are: creating expressive verbal communication with 13 statements; creating supportive nonverbal communication with five statements; creating communication with another culture (cross-cultural) with nine statements; creating receptive communication as a listener with nine statements; and creating healthy relationships (relational) with seven statements. Before the administration of the questionnaire, the researcher had it content validated by one $\mathrm{PhD}$ in English, one $\mathrm{PhD}$ in Educational Management and three $\mathrm{PhD}$ candidates. Their suggestions were incorporated in the final version.

\section{Participants of the Study}

There were 314 active seafarers and MAAP cadets who answered the questionnaire. The population includes 45 ratings, 60 operational level officers, 22 management level officers, 94 deck cadets and 93 engine cadets. Also, these respondents were divided into two, the deck group and the engine group, to have a clearer basis for designing the course specification for Speech Communication with IMO SMCP.

For the midshipmen of MAAP, the researcher distributed the questionnaire and had the participants personally write their answer to each item. For the active seafarers, the data was gathered through online communication, mostly through Facebook Messenger.

\section{Data Analysis and Interpretation}

The Cronbach Alpha determined the reliability of the items in the questionnaire to be 0.92 , suggesting high internal consistency. Further, weighted means were computed for the responses of the population in the different areas of communicative behavior. Significant differences of means across different groups were determined using Analysis of Variance (ANOVA) since this statistical tool is appropriately used to determine significant differences between two or more groups (Hechanova \& Hechanova, 2002). Moreover, the level of significance was set at .05. All these statistical computations were carried using 
SPSSv18 which readily provides the probability values for comparison with the significance level.

For the interpretation of table on the communicative behaviors of Filipino seafarers, the following scale was used.

\begin{tabular}{|l|c|}
\hline Scale of Means & Descriptive Equivalent/Interpretation \\
\hline $1.00-1.49$ & Never Practiced \\
\hline $1.50-2.49$ & Rarely Practiced \\
\hline $2.50-3.49$ & Sometimes Practiced \\
\hline $3.50-4.49$ & Practiced Often \\
\hline $4.50-5.00$ & Always Practiced \\
\hline
\end{tabular}

\section{Results}

Based on the responses of the participants, the section that follows present the answers to the specific questions raised by this study.

\section{Q1. Communicative Behaviors of Filipino Seafarers}

Table 1 below shows the communicative behaviors of active Filipino seafarers and MAAP students who have boarded international vessels during their shipboard training. As can be seen, all the respondents exhibit all the desirable areas of communication as they practice these very often. Among these areas, creating expressive verbal communication has the lowest rating $(\mathrm{M}=4.01, \mathrm{SD}=.45)$. This area covers the manner of oral communication of Filipino seafarers, including their use of gestures, their pronunciation, their pacing and their attitude toward their statements and other people's statements. On the other hand, cross-cultural communication has the highest rating $(\mathrm{M}=4.21, \mathrm{SD}=.49)$ among the different areas.

Table 1. Communicative Behaviors of Filipino Seafarers

\begin{tabular}{|c|c|c|c|c|c|c|c|c|c|c|}
\hline \multirow[t]{2}{*}{ Areas } & \multicolumn{2}{|c|}{$\begin{array}{c}\text { Active Deck } \\
\text { Seafarers } \\
\end{array}$} & \multicolumn{2}{|c|}{$\begin{array}{c}\text { Active } \\
\text { Engine } \\
\text { Seafarers }\end{array}$} & \multicolumn{2}{|c|}{$\begin{array}{l}\text { Deck } \\
\text { Cadets }\end{array}$} & \multicolumn{2}{|c|}{$\begin{array}{l}\text { Engine } \\
\text { Cadets }\end{array}$} & \multicolumn{2}{|c|}{ Total } \\
\hline & Mean & $S D$ & Mean & $S D$ & Mean & $S D$ & Mean & $S D$ & Mean & $n S D$ \\
\hline $\begin{array}{l}\text { Creating Expressive Verbal } \\
\text { Communication }\end{array}$ & 4.11 & 0.42 & 3.90 & 0.46 & 4.10 & 0.44 & 3.92 & .44 & 4.01 & .45 \\
\hline $\begin{array}{l}\text { Creating Supportive } \\
\text { Nonverbal Communication }\end{array}$ & 4.22 & 0.57 & 4.04 & 0.53 & 4.17 & 0.46 & 4.03 & .47 & 4.12 & .51 \\
\hline $\begin{array}{l}\text { Creating Communication } \\
\text { with Another Culture } \\
\text { (Cross-Cultural) } \\
\end{array}$ & 4.34 & 0.54 & 4.07 & 0.49 & 4.30 & 0.42 & 4.09 & .49 & 4.21 & .49 \\
\hline $\begin{array}{l}\text { Creating Receptive } \\
\text { Communication as a } \\
\text { Listener (Effective Listening) }\end{array}$ & 4.25 & 0.50 & 4.01 & 0.48 & 4.15 & 0.47 & 3.97 & .51 & 4.10 & .50 \\
\hline $\begin{array}{l}\text { Creating Healthy } \\
\text { Relationships (Relational) }\end{array}$ & 4.35 & 0.53 & 4.16 & 0.61 & 4.17 & 0.51 & 3.99 & .55 & 4.16 & .56 \\
\hline Overall & 4.25 & 0.42 & 4.04 & 0.39 & 4.18 & 0.38 & 4.00 & .37 & 4.12 & .40 \\
\hline
\end{tabular}




\section{Q2. Difference in the Communicative Behaviors of Filipino Seafarers}

Table 2 below shows the result for the difference between the four groups of respondents. Using ANOVA, significant differences were detected ( $\mathrm{f}<0.05$ ) among the different groups of participants, namely the active deck seafarers, MAAP deck cadets, MAAP engine cadets and the ective engine seafarers . Using the least significant difference (LSD) test, it was identified that the significant differences lie between the deck group and the engine group, except for the area of creating healthy relationships where the mean score of active deck seafarers significantly differ from the mean score of MAAP deck cadets, from the mean score of active engine seafarers and from the mean score of the MAAP engine cadets.

Table 2. Communicative Behaviors of Filipino Seafarers According to Field of Work

\begin{tabular}{|c|c|c|c|c|c|}
\hline \multirow{2}{*}{ Area } & \multirow{2}{*}{ Field } & \multicolumn{3}{|c|}{ Descriptives } & \multirow[t]{2}{*}{$\mathbf{F}$} \\
\hline & & $N$ & Mean & $S D$ & \\
\hline \multirow{4}{*}{$\begin{array}{l}\text { Creating Expressive } \\
\text { Verbal Communication }\end{array}$} & Active Deck Seafarers & 79 & 4.11 & .42 & \multirow[t]{4}{*}{$4.88 *$} \\
\hline & MAAP Deck & 89 & 4.10 & .44 & \\
\hline & MAAP Engine & 88 & 3.92 & .44 & \\
\hline & $\begin{array}{c}\text { Active Engine } \\
\text { Seafarers }\end{array}$ & 58 & 3.90 & .46 & \\
\hline \multirow{4}{*}{$\begin{array}{l}\text { Creating Supportive } \\
\text { Nonverbal } \\
\text { Communication }\end{array}$} & Active Deck Seafarers & 79 & 4.22 & .57 & \multirow[t]{4}{*}{$2.71 *$} \\
\hline & MAAP Deck & 89 & 4.17 & .46 & \\
\hline & $\begin{array}{c}\text { Active Engine } \\
\text { Seafarers } \\
\end{array}$ & 58 & 4.04 & .53 & \\
\hline & MAAP Engine & 88 & 4.03 & .47 & \\
\hline \multirow{4}{*}{$\begin{array}{l}\text { Creating Communication } \\
\text { with Another Culture } \\
\text { (Cross-Cultural) }\end{array}$} & Active Deck Seafarers & 79 & 4.34 & .54 & \multirow[t]{4}{*}{$6.53 *$} \\
\hline & MAAP Deck & 89 & 4.30 & .42 & \\
\hline & MAAP Engine & 88 & 4.09 & .49 & \\
\hline & $\begin{array}{c}\text { Active Engine } \\
\text { Seafarers }\end{array}$ & 58 & 4.07 & .49 & \\
\hline \multirow{4}{*}{$\begin{array}{l}\text { Creating Receptive } \\
\text { Communication as a } \\
\text { Listener (Effective } \\
\text { Listening) }\end{array}$} & Active Deck Seafarers & 78 & 4.25 & .50 & \multirow[t]{4}{*}{$5.62 *$} \\
\hline & MAAP Deck & 89 & 4.15 & .47 & \\
\hline & $\begin{array}{c}\text { Active Engine } \\
\text { Seafarers }\end{array}$ & 58 & 4.01 & .48 & \\
\hline & MAAP Engine & 88 & 3.97 & .51 & \\
\hline \multirow{4}{*}{$\begin{array}{l}\text { Creating } \\
\text { Relationships } \\
\text { (Relational) }\end{array}$} & Active Deck Seafarers & 78 & 4.35 & .53 & \multirow[t]{4}{*}{$6.04 *$} \\
\hline & MAAP Deck & 89 & 4.17 & .51 & \\
\hline & $\begin{array}{c}\text { Active Engine } \\
\text { Seafarers } \\
\end{array}$ & 58 & 4.16 & .61 & \\
\hline & MAAP Engine & 88 & 3.99 & .55 & \\
\hline \multirow[t]{4}{*}{ Overall } & Active Deck Seafarers & 79 & 4.25 & .42 & \multirow[t]{4}{*}{$7.40 *$} \\
\hline & MAAP Deck & 89 & 4.18 & .38 & \\
\hline & $\begin{array}{c}\text { Active Engine } \\
\text { Seafarers }\end{array}$ & 58 & 4.04 & .39 & \\
\hline & MAAP Engine & 88 & 4.00 & .37 & \\
\hline
\end{tabular}

$* p<0.05$ 
Though it is indicated in the overall row and columns that the two groups have composite means equivalent to 'practiced often,' the deck group is performing the specific communicative behaviors more often than the engine group. This difference is shown by the mean scores of the respondents: active deck seafarers $(\mathrm{M}=4.25, \mathrm{SD}=.50)$; MAAP deck cadets $(\mathrm{M}=4.18, \mathrm{SD}=.38)$; active engine seafarers $(\mathrm{M}=4.04, \mathrm{SD}=.39)$; and MAAP engine cadets $(\mathrm{M}=4.00, .37)$. It can also be seen that the active deck seafarers have the highest mean score, indicating that they exhibit the desirable communicative behaviors more often than the other respondents.

\section{Q3. Areas of Communicative Behavior That Need Improvement}

This study focused on those specific items where the respondents have the lowest mean score. Using the statements under the five areas, this study determined the practice/s where the Filipinos need some improvements. There are 43 statements for all the five areas. Out of these statements, 41 are practiced often by the Filipino seafarers while two are sometimes practiced, one by engine cadets and the other one by active engine seafarers.

There are 13 statements of practices under the first area Creating expressive verbal communication as shown in Table 3. Filipino seafarers as a whole have the lowest score (3.54) for the statement "I comment about other people's behavior, and not on what I imagine them to be". Taken as separate groups, the active deck seafarers have the lowest score (3.53) for the statement "I comment about other people's behavior, and not on what I imagine them to be"; and the active engine seafarers have the lowest score (3.10) for the statement "I focus on what other people say, not on why they say it" because they just practice it sometimes.

For MAAP deck cadets, the statement "I comment about other people's behavior, and not on what I imagine them to be" got the lowest score (3.73). The engine cadets, on the other hand, sometimes use English when they communicate with their crewmates that is why this statement got the lowest score (3.33).

The next area of communicative behavior, creating supportive nonverbal communication, has five specific practices. As shown in Table 4, all the respondents got the lowest score for the statement "I use touch to reinforce my message, but with caution, taking into consideration the cultural differences and individual preferences of people I talk with" (3.83). Grouped individually, each group obtained the following mean scores with the same descriptive equivalent of practiced often: 3.91 for active deck seafarers, 3.60 for active engine seafarers, 3.94 for deck cadets, and 3.81 for engine cadets. 
Table 3. Creating Expressive Verbal Communication

\begin{tabular}{|l|c|c|c|c|c|}
\hline Statements & $\begin{array}{c}\text { Active } \\
\text { Deck } \\
\text { Seafarers }\end{array}$ & $\begin{array}{c}\text { Active } \\
\text { Engine } \\
\text { Seafarers }\end{array}$ & $\begin{array}{c}\text { MAAP } \\
\text { Deck }\end{array}$ & MAAP & Engine \\
Average \\
\hline $\begin{array}{l}\text { 1. I repeat what I say when my crewmates } \\
\text { do not understand me. }\end{array}$ & 4.53 & 4.38 & 4.48 & 4.32 & 4.43 \\
\hline $\begin{array}{l}\text { 2. I own responsibility for my statements } \\
\text { so I don't blame others for what I say. }\end{array}$ & 4.38 & 4.48 & 4.25 & 4.01 & 4.26 \\
\hline $\begin{array}{l}\text { 3. I adjust my pace in speaking to make } \\
\text { sure my crewmates understand me. }\end{array}$ & 4.35 & 4.31 & 4.17 & 4.22 & 4.25 \\
\hline $\begin{array}{l}\text { 4. I adjust my pronunciation to make sure } \\
\text { my crewmates understand me. }\end{array}$ & 4.47 & 4.22 & 4.06 & 4.18 & 4.23 \\
\hline $\begin{array}{l}\text { 5. I use concrete terms, not vague } \\
\text { language. }\end{array}$ & 4.19 & 4.21 & 4.27 & 4.09 & 4.19 \\
\hline $\begin{array}{l}\text { 6. I share ideas based on my observations, } \\
\text { not based on my assumptions. }\end{array}$ & 4.36 & 4.26 & 4.26 & 3.93 & 4.19 \\
\hline $\begin{array}{l}\text { 7. I match my voice, gestures and body } \\
\text { language with my verbal messages. }\end{array}$ & 4.29 & 4.07 & 4.25 & 4.10 & 4.19 \\
\hline $\begin{array}{l}\text { 8. I don't use extreme descriptions in my } \\
\text { statements; rather, I describe in terms of } \\
\text { degree. }\end{array}$ & 3.99 & 3.70 & 4.09 & 3.97 & 3.96 \\
\hline $\begin{array}{l}\text { 9. I use SMCP as the need arises. } \\
\text { 10. I avoid evaluating others and giving } \\
\text { them pieces of advice without being asked. }\end{array}$ & 3.85 & 3.55 & 3.98 & 3.91 & 3.85 \\
\hline $\begin{array}{l}\text { 11. I use English when I communicate } \\
\text { with my crewmates. }\end{array}$ & 3.67 & 3.50 & 3.79 & 3.33 & 3.58 \\
\hline $\begin{array}{l}\text { 12. I focus on what other people say, not } \\
\text { on why they say it. }\end{array}$ & 3.66 & 3.10 & 3.75 & 3.58 & 3.56 \\
\hline $\begin{array}{l}\text { 13. I comment about other people's } \\
\text { behavior, and not on what I imagine them } \\
\text { to be. }\end{array}$ & 3.53 & 3.30 & 3.73 & 3.52 & 3.54 \\
\hline \begin{tabular}{l} 
Composite \\
\hline
\end{tabular} & 4.11 & 3.90 & 4.10 & 3.92 & 4.01 \\
\hline
\end{tabular}

Table 4. Creating Supportive Non-verbal Communication

\begin{tabular}{|l|c|c|c|c|c|}
\hline Statements & $\begin{array}{c}\text { Active } \\
\text { Deck } \\
\text { Seafarers }\end{array}$ & $\begin{array}{c}\text { Active } \\
\text { Engine } \\
\text { Seafarers }\end{array}$ & $\begin{array}{c}\text { MAAP } \\
\text { Deck }\end{array}$ & $\begin{array}{l}\text { MAAP } \\
\text { Engine }\end{array}$ & Average \\
\hline $\begin{array}{l}\text { 1. I lend a helping hand to my crewmates } \\
\text { onboard. }\end{array}$ & 4.51 & 4.40 & 4.44 & 4.30 & 4.41 \\
\hline $\begin{array}{l}\text { 2. I do things to connect with my crewmates } \\
\text { onboard. }\end{array}$ & 4.37 & 4.19 & 4.10 & 4.14 & 4.19 \\
\hline $\begin{array}{l}\text { 3. I use my body, posture, eye contact, arms } \\
\text { and voice to create an open, welcoming and } \\
\text { caring attitude toward others. }\end{array}$ & 4.22 & 4.05 & 4.26 & 4.06 & 4.15 \\
\hline $\begin{array}{l}\text { 4. I create uplifting experiences for my } \\
\text { crewmates by doing little things for them. }\end{array}$ & 4.08 & 4.04 & 4.12 & 3.84 & 4.02 \\
\hline $\begin{array}{l}\text { 5. I use touch to reinforce my message, but } \\
\text { with caution, taking into consideration the } \\
\text { cultural differences and individual } \\
\text { preferences of people I talk with. }\end{array}$ & 3.91 & 3.60 & 3.94 & 3.81 & 3.83 \\
\hline \begin{tabular}{l} 
Composite \\
\hline
\end{tabular} & 4.22 & 4.04 & 4.17 & 4.03 & 4.12 \\
\hline
\end{tabular}


Table 5. Creating Communication with another Culture

\begin{tabular}{|c|c|c|c|c|c|}
\hline Statements & $\begin{array}{l}\text { Active } \\
\text { Deck } \\
\text { Seafarers }\end{array}$ & $\begin{array}{c}\text { Active } \\
\text { Engine } \\
\text { Seafarers }\end{array}$ & $\begin{array}{l}\text { MAAP } \\
\text { Deck }\end{array}$ & $\begin{array}{l}\text { MAAP } \\
\text { Engine }\end{array}$ & Average \\
\hline $\begin{array}{l}\text { 1. I accept and appreciate the fact that people } \\
\text { are unique and different from me. }\end{array}$ & 4.42 & 4.34 & 4.40 & 4.25 & 4.35 \\
\hline $\begin{array}{l}\text { 2. When I communicate with people from } \\
\text { other cultures, I listen without interrupting. }\end{array}$ & 4.52 & 4.21 & 4.42 & 4.22 & 4.35 \\
\hline $\begin{array}{l}\text { 3. I create friendships with my crewmates } \\
\text { onboard by extending our initial conversation } \\
\text { to other more meaningful conversations. }\end{array}$ & 4.53 & 4.09 & 4.46 & 4.06 & 4.29 \\
\hline $\begin{array}{l}\text { 4. When I communicate with other people } \\
\text { onboard, I try to create an atmosphere where the } \\
\text { other person feels safe to speak, encouraged to } \\
\text { disclose, and happy to be chatting with me. }\end{array}$ & 4.47 & 4.09 & 4.26 & 4.16 & 4.25 \\
\hline $\begin{array}{l}\text { 5. When I communicate with other people } \\
\text { from other cultures, I try to convey an attitude } \\
\text { of wanting to learn and not wanting to judge } \\
\text { or teach, wanting to explore and not wanting } \\
\text { to direct or guide. }\end{array}$ & 4.41 & 4.16 & 4.30 & 4.06 & 4.23 \\
\hline $\begin{array}{l}\text { 6. I create a communicative place where the } \\
\text { other person from a different culture and I can } \\
\text { meet and share human experiences. }\end{array}$ & 4.29 & 3.95 & 4.26 & 4.01 & 4.14 \\
\hline $\begin{array}{l}\text { 7. I increase my cultural reference to include } \\
\text { more people by enlarging my circle of "us" } \\
\text { (the same group or culture) to include more of } \\
\text { "them" (other groups or cultures). }\end{array}$ & 4.20 & 3.91 & 4.28 & 4.03 & 4.12 \\
\hline $\begin{array}{l}\text { 8. Onboard, I go out of my cultural comfort } \\
\text { zone, take the risk and experience new things } \\
\text { with my crewmates who belong to other } \\
\text { cultures. }\end{array}$ & 4.05 & 3.97 & 4.26 & 4.02 & 4.09 \\
\hline $\begin{array}{l}\text { 9. I ask my crewmates about their culture, } \\
\text { perceptions, thoughts and feelings so I can } \\
\text { increase my cultural frame of reference and so } \\
\text { they can open up and feel comfortable with me. }\end{array}$ & 4.24 & 3.97 & 4.10 & 4.01 & 4.09 \\
\hline Composite & 4.34 & 4.07 & 4.30 & 4.09 & 4.21 \\
\hline
\end{tabular}

The third area of communicative behavior deals with how the Filipino seafarers treat cultural diversity on board and how they communicate with those who are from other countries and cultural backgrounds (Table 5). While the Filipino seafarers practice very often the specific behaviors itemized in the questionnaire, they got the lowest mean score for the items, "On board, I go out of my cultural comfort zone, take the risk and experience new things with my crewmates who belong to other cultures" and "I ask my crewmates about their culture, perceptions, thoughts and feelings so I can increase my cultural frame of reference and so they can open up and feel comfortable with me." The different groups of respondents had the lowest mean scores for the following items: Active deck seafarers- "On board, I go out of my cultural comfort zone, take the risk and experience new things with my crewmates who belong to other cultures" (4.05); Active engine seafarers- "I increase my cultural reference to include more people by enlarging my circle of 'us' to include more of 'them"' (3.91); deck cadets- "I ask my 
crewmates about their culture, perceptions, thoughts and feelings so I can increase my cultural frame of reference and so they can open up and feel comfortable with me" (4.10); engine cadets- the same with deck cadets but with another statement having the same mean value of 4.01 and that is "I create a communicative place where the other person from a different culture and I can meet and share human experiences."

Table 6. Creating Receptive Communication as a Listener

\begin{tabular}{|c|c|c|c|c|c|}
\hline Statements & $\begin{array}{l}\text { Active } \\
\text { Deck } \\
\text { Seafarers }\end{array}$ & \begin{tabular}{|c|} 
Active \\
Engine \\
Seafarers
\end{tabular} & $\begin{array}{l}\text { MAAP } \\
\text { Deck }\end{array}$ & $\begin{array}{l}\text { MAAP } \\
\text { Engine }\end{array}$ & Average \\
\hline $\begin{array}{l}\text { 1. When I communicate with my crewmates, } \\
\text { I show them my support by my words of } \\
\text { encouragement, gestures of support and } \\
\text { friendly invitations. }\end{array}$ & 4.37 & 4.19 & 4.31 & 3.98 & 4.21 \\
\hline $\begin{array}{l}\text { 2. When I communicate with my crewmates, } \\
\text { I attend to them verbally by: }\end{array}$ & 4.34 & 4.08 & 4.23 & 4.11 & 4.20 \\
\hline a. voicing interest, concern and understanding & 4.35 & 4.09 & 4.35 & 4.13 & 4.24 \\
\hline b. telling the speaker to continue sharing & 4.31 & 4.05 & 4.13 & 4.01 & 4.13 \\
\hline $\begin{array}{l}\text { c. telling the speaker I am interested in } \\
\text { what he or she is saying }\end{array}$ & 4.28 & 4.11 & 4.22 & 4.07 & 4.18 \\
\hline d. encouraging them to share more & 4.44 & 4.06 & 4.20 & 4.24 & 4.25 \\
\hline $\begin{array}{l}\text { 3. When I communicate with my crewmates, } \\
\text { I reflect or paraphrase what they are saying to } \\
\text { clarify, negotiate and demonstrate my } \\
\text { understanding. }\end{array}$ & 4.30 & 4.12 & 4.19 & 4.03 & 4.16 \\
\hline $\begin{array}{l}\text { 4. When I communicate with my crewmates, } \\
\text { I make them feel that they have my } \\
\text { undivided attention. }\end{array}$ & 4.22 & 4.11 & 4.25 & 4.02 & 4.15 \\
\hline $\begin{array}{l}\text { 5. When I communicate with my crewmates, } \\
\text { I make sure I am physically present and I } \\
\text { make them feel that there is nowhere else I } \\
\text { would rather be. }\end{array}$ & 4.28 & 4.02 & 4.21 & 3.99 & 4.13 \\
\hline $\begin{array}{l}\text { 6. When I communicate with my crewmates, } \\
\text { I try to be open to their thoughts and feelings. }\end{array}$ & 4.34 & 4.00 & 4.06 & 3.92 & 4.08 \\
\hline $\begin{array}{l}\text { 7. When I communicate with my crewmates, } \\
\text { I shift the spotlight from myself to them, to } \\
\text { elevate them above me, and to make room } \\
\text { for their thoughts, opinions and feelings. }\end{array}$ & 4.23 & 3.98 & 3.98 & 3.99 & 4.04 \\
\hline $\begin{array}{l}\text { 8. When I communicate with my crewmates, } \\
\text { I attend to them verbally: }\end{array}$ & 4.05 & 3.92 & 4.16 & 4.00 & 4.04 \\
\hline a. open and relaxed posture & 4.28 & 4.09 & 4.26 & 4.14 & 4.20 \\
\hline b. silence & 3.87 & 3.84 & 3.91 & 3.90 & 3.88 \\
\hline c. direct eye contact & 4.24 & 4.04 & 4.25 & 4.17 & 4.19 \\
\hline d. affirmative nodding & 4.04 & 3.93 & 4.29 & 4.03 & 4.09 \\
\hline e. warm facial expressions & 4.08 & 3.91 & 4.21 & 4.05 & 4.08 \\
\hline f. appropriate touching of support & 3.78 & 3.69 & 4.06 & 3.73 & 3.83 \\
\hline $\begin{array}{l}\text { 9. When I communicate with my crewmates, } \\
\text { I put aside my opinions, my preferences, and } \\
\text { my prejudices. }\end{array}$ & 4.13 & 3.69 & 3.97 & 3.65 & 3.87 \\
\hline Composite & 4.25 & 4.01 & 4.15 & 3.97 & 4.10 \\
\hline
\end{tabular}


Table 6 presents the data for the fourth area of communicative behavior, creating receptive communication as a listener. Here, the Filipino seafarers perform the specified statements often with their composite mean of 4.10. They got the lowest mean score of 3.83 (practiced often) for the statement "When I communicate with my crewmates, I attend to them nonverbally with appropriate touching of support." Taken as separate groups, both the active deck and engine seafarers scored lowest in the same statement (When I communicate with my crewmates, I attend to them nonverbally with appropriate touching of support) with mean values of 3.78 and 3.69, respectively. Aside from the said statement, the active engine seafarers also scored 3.69 in the statement "When I communicate with my crewmates, I put aside my opinions, my preferences, and my prejudices." For deck cadets, they have the lowest mean score for the statement "When I communicate with my crewmates, I attend to them nonverbally through silence." For the engine cadets, they have the same item with the active engine seafarers. The engine cadets are also lowest in practicing the statement "When I communicate with my crewmates, I put aside my opinions, my preferences, and my prejudices."

Table 7 summarizes the data for the last area of communicative behavior is creating healthy relationships, which deals with how Filipino seafarers reach out to others and how they maintain good working relationships with their crewmates. Of all the seven statements under this area, the Filipino seafarers got the lowest mean score of 3.98 (practiced often) in the statement "I open up to my crewmates. "The active deck seafarers, active engine seafarers and the engine cadets are also lowest in the same statement with respective mean scores of 4.18, 3.93, and 3.73; all have the same descriptive equivalent of practiced often. The deck cadets are lowest in the statement "When I communicate with my crewmates, they become better" with a mean score of 4.06 (practiced often).

Table 7. Creating Healthy Relationships

\begin{tabular}{|l|c|c|c|c|c|}
\hline Statements & $\begin{array}{c}\text { Active } \\
\text { Deck } \\
\text { Seafarers }\end{array}$ & $\begin{array}{c}\text { Active } \\
\text { Engine }\end{array}$ & $\begin{array}{c}\text { MAAP } \\
\text { Deck }\end{array}$ & $\begin{array}{c}\text { MAAP } \\
\text { Engine }\end{array}$ & Average \\
\hline $\begin{array}{l}\text { 1. I am willing to reach out and connect to my } \\
\text { crewmates. }\end{array}$ & 4.51 & 4.28 & 4.44 & 4.19 & 4.36 \\
\hline $\begin{array}{l}\text { 2. When I communicate with my crewmates, } \\
\text { I discover new things about myself and about } \\
\text { them. }\end{array}$ & 4.40 & 4.30 & 4.15 & 4.08 & 4.22 \\
\hline $\begin{array}{l}\text { 3. When I communicate with my crewmates, } \\
\text { I feel that we keep an open mind, a flexible } \\
\text { attitude and a willingness to try new things. }\end{array}$ & 4.42 & 4.21 & 4.27 & 4.01 & 4.22 \\
\hline $\begin{array}{l}\text { 4. When I communicate with my crewmates, } \\
\text { I feel that they are encouraged. }\end{array}$ & 4.31 & 4.16 & 4.16 & 4.00 & 4.15 \\
\hline $\begin{array}{l}\text { 5. When I communicate with my crewmates, } \\
\text { I feel that they are inspired. }\end{array}$ & 4.32 & 4.12 & 4.08 & 3.97 & 4.12 \\
\hline $\begin{array}{l}\text { 6. When I communicate with my crewmates, } \\
\text { I feel that they become better. }\end{array}$ & 4.35 & 4.05 & 4.06 & 3.98 & 4.11 \\
\hline $\begin{array}{l}\text { 7. I open up to my crewmates. } \\
\text { Composite }\end{array}$ & 4.18 & 3.93 & 4.08 & 3.73 & 3.98 \\
\hline
\end{tabular}




\section{Discussion}

Based on the findings, this paper concludes that Filipino seafarers, including those maritime students who have gone on board for their shipboard training, are communicatively competent as evidenced by their practicing often the ideal behaviors of effective interlocutors. Filipino seafarers got the highest mean score in the area of creating communications with another culture probably because Filipinos are a blend of different races (Andres, 2006) and this perhaps makes them flexible and adaptive.

The significant differences in the communicative behaviors of the deck and the engine group, with the deck group performing the pre-determined behaviors more than the engine group, may be explained by the nature of their job. The deck people are exposed to a lot of communication opportunities since they are the ones who usually talk and negotiate with other people aside from the crew members. They face port authorities, surveyors, agents, and they are the ones communicating with other ships.

Engine people have very limited time to communicate between and among themselves. And when they do, they use sign language because the engine area is very noisy. During toolbox meetings, only one is talking most of the times and the meeting lasts for 10-15 minutes, and then they go to their respective job assignments. For the deck, when they have their watch, the bridge is a good avenue to communicate so they exhibit the behaviors often, and they have more chances to make the necessary communication adjustments.

Looking at the bigger picture, Filipino seafarers are mostly men and the shipping industry is dominated by men so this must be the reason why they do not always use physical touch to reinforce their message. They may not be very comfortable with it. About culture, though it was mentioned that Filipinos can adjust easily, they may also be encouraged to be more interested in knowing and welcoming other cultures in their circle. Also, they may also be encouraged to talk about their own culture to the other nationalities on board. Through these, they can totally avoid having conflicts with their crewmates because of cultural differences.

While Parsons, Potoker, Progoulaki, and Batiduan (2011) mentioned that there was no explicit inclusion of cultural awareness in the maritime courses curriculum, this study proves that Filipinos are still able to cope with cultural differences. They might just need to continue improving their verbal communication behaviors as this came out to be where they performed the least. This paper recommends that Filipino maritime students be trained to speak English at all times, to focus on the message and not its reason, and to always use SMCP in their internal and external communications.

For a start, the researcher advances the inclusion of all the areas of effective communication in the Maritime English course manual to be designed. This will ensure that maritime students are equipped with the skills in all areas of communication. The new course of Maritime English has the descriptive title "Speech Communication with SMCP." This means that the oral communication skills of the cadets or any maritime student should be developed, honed and 
enhanced. Even so, speech communication does not cover speaking only; it also includes those nonverbal aspects that accompany the spoken message, the gestures, body movements, facial expression and other behaviors like listening. Hence, speech communication as a course should be delivered in its totality.

For several years, Maritime English course has focused on using SMCP. The students were brought to the simulation centers and were guided and practiced to appropriately use SMCP in their internal and external communication. This has yielded very positive results as evinced by the communicative practice of the respondents. Nevertheless, the gauge of actual performance from the viewpoint of recipients or those whom these Filipino seafarers interact with is currently unavailable, and this study recognizes that shortcoming. In addition, the nonverbal, listening and intercultural communication skills of the maritime students were not specifically and definitely taken up during the duration of the course. They are just mentioned as part of the communication process.

For the course manual to be developed, opportunities for using SMCP should be maximized while making sure that students are trained to practice the ideal listening and nonverbal skills, and intercultural communication skills. These have to be taken as separate topics, so they are given due and ample time. More specifically, culture and how it affects communication have to be given importance in the development of the course. As Guessabi (2016) said, "language is culture and culture is language." This area has always been taken for granted. The Appendix presents a proposed course specification for Speech Communication with SMCP. It contains the suggested terminal learning outcomes and the topics to be covered.

Facilitators in the maritime sector may also have a vital role to play in making sure that these students are equipped with communication skills needed on board multilingual and multicultural crew. As Noble (2011) noted, teachers may encourage the maritime students early on to move out of their comfort zones or circles of friends and company to welcome and be with those from other ethnic and language groups. This way, they get used to being blended with other people who do not belong to their "circle" as early as possible. This eventually results in the maritime students being comfortable working with other people, thereby avoiding problems that may occur due to cultural and linguistic differences.

The findings of this study may also be said to neutralize the suggestions of Badawi and Halawa (2003) and Rehman (2007) on the need to include crosscultural differences or cultural awareness and communication skills in the course offerings. Filipino seafarers showed in their responses that they have no problem with their communication skills and their communication with other cultures. Nevertheless, these areas need not be neglected in their training and education. They should be further strengthened through inclusions of practiced and natural conversations with other nationalities in the course. Going further, immersions or exchange students programs with other maritime schools outside the country may also be arranged.

Considering the huge number of Filipino seafarers manning the different ships around the world, this study acknowledges the fact that the data may not represent the whole population of Filipinos working at sea. Also, while this 
study proved that the participants are communicatively competent, no data was gathered from those whom they interact with. Moreover, the researcher did not separate those respondents who work with a multilingual crew and a full crew. This variable may have affected the outcome of this study.

With the limitations mentioned above, this paper suggests a conduct of a more thorough and more comprehensive research that includes the feedbacks of the recipients of the messages, observation of the communicative behaviors of Filipino mariners, interview with the respondents, and an inclusion of a bigger population.

\section{References}

Andres, T. (2006). Understanding the Filipino seaman: His values, attitude and behavior. University of Michigan: Giraffe Books.

Badawi, E., \& Halawa, A. (2003). Maritime communication: The problem of cross cultural and multilingual crews, $4^{\text {th }}$ IAMU General Assembly. Retrieved from http://bit.ly/ 2vJiw3A.

Baylon, A., \& Santos, E. (2011). The challenges in Philippine maritime education and training. International Journal of Innovative Interdisciplinary Research, 1(1), 34-43. Retrieved from http://bit.ly/2xx72lT.

Fujishin, R. (2009). Creating communication: Exploring and expanding your fundamental communication skills, $2^{\text {nd }}$ ed. Maryland: Rowman \& Littlefield Publishers.

Guessabi, F. (2016). Blurring the line between language and culture. The Journal of Communication and Education, Language Magazine. Retrieved from http://bit.ly/ 2x3PrEa.

Hechanova, R., \& Hechanova, R. (2002). Analysis of variance with emphasis on mean separation. Cabanatuan City: Blas Edward's Inc.

Horck, J. (2008, May 19-21). Cultural and gender diversities affecting the ship/port interface. Paper presented at the First International Ship Port Interface Conference (ISPIC 2008), Bremen, Germany. Retrieved from http://bit.ly/2gowXYY.

International Maritime Organization (IMO). (2011). STCW including the Manila amendments: STCW convention and STCW code. London: International Maritime Organization.

International Maritime Organization (IMO). (2000). IMO standard marine communication phrases. Retrieved from http://bit.ly/2wS85Qk.

Ion, A. (2012). Cultural diversity on board ships. Retrieved from http://bit.ly/2whxWiZ.

Kabylbekova, D., Ashirimbetova, M. \& Akhmetzhanova, Z. (2013). Pre-service teachers' awareness of communicative behavior variations in translated film discourse. ProcediaSocial and Behavioral Sciences, 122(2014), 29-34.

Karthik, K. (2014). Consequence of cross cultural misunderstanding- A shipboard perspective. Indian Journal of Science and Technology, 7(7), 6-9.

Kotorova, E. (2014). Decsribing cross-cultural speech behaviour: A communicativepragmatic field approach. Procedia- Social and Behavioral Sciences, 154(2014), 184-192. Retrieved from http://bit.ly/2xM9eVZ.

Nakazawa, T. (2014). Maritime English- is this the only way to communicate? Proceedings of the $4^{\text {th }}$ IAMU General Assembly. Retrieved from http://bit.ly/2x4icAN.

Noble, A. (2011). Make the most of diversity. Retrieved from http://bit.ly/2wIrdj6.

Parsons, J., Potoker, E., Progoulaki, M., \& Batiduan, B. (2011, June 9-10). Cross-cultural competence for maritime professionals through education and training. Paper presented 
at the $37^{\text {th }}$ Annual General Assembly of International Federation of Shipmaster's Association, Halifax, Canada. Retrieved from http://bit.ly/2vJJiZG.

Popescu, C., \& Varsami, A. (2010). Maritime English- A necessity for nowadays apprentices. Paper presented at the $3^{\text {rd }}$ International Conference on Maritime and Naval Science and Engineering, Constantza, Romania. Retrieved from http://bit.ly/ 2iIxrcS.

Pressman, H., Pietrzyk, A., \& Schneider, J. (2011). Overcoming communication barriers in emergency situations: Some basic tools. Retrieved from http://bit.ly/2wnCvGQ.

Pyne, R., \& Koester, T. (2005). Methods and means for analysis of crew communication in the maritime domain. The Archives of Transport, 7(3-4). Retrieved from http://bit.ly/ $2 \mathrm{vqXMCd}$.

Rashed, S., \& Kamal, A. (2010). Maritime English holds a great stake in the both safety and security of merchant vessels. Proceedings of IMLA-IMEC 22, Alexandria, Egypt. Retrieved from http://bit.ly/2vDDQsd.

Rehman, A. (2007). Communication skills and cultural awareness: Model course (Dissertation). Retrieved from http://bit.ly/2wILx3K.

Tran, T. (2007). Cultural sensitivity education: Limiting the adverse effects of multicultural crewing in shipping (Dissertation). Retrieved from http://bit.ly/2illq7p.

University of Pittsburgh. (2007). Communicative behaviors for effective group work. Retrieved from http://bit.ly/26qrDEH. 


\section{Appendix}

Proposed Terminal Learning Outcomes and Topics for Speech Communication with

$$
\text { IMO SMCP }
$$

Course: Speech Communication with SMCP

\section{Terminal Learning Outcomes:}

TLO1- illustrate and explain the communication process specifically considering the aspects of listening and culture;

TLO2- deliver an argumentative/position speech using appropriate kinesic communication strategies;

TLO3- listen and respond appropriately to messages conveyed in a role play;

TLO4- use SMCP in internal and external communications during the different ship operations.

\section{Topics:}

1. Communication (18 hours)

a. What is communication? (3 hours)

b. The role of listening in communication (6 hours)

c. The role of culture in communication ( 3 hours)

d. The communication between and among multilingual crew ( 3 hours)

e. Non-verbal communication (3 hours)

2. Oral modes of communication (15 hours)

a. Daily conversations, focusing on on-board communications (5 hours)

b. Extemporaneous speech (5 hours)

c. Argumentative speech (5 hours)

3. Standard Marine Communication Phrases (15 hours)
a. What is SMCP? (1 hour)
b. The role of SMCP in shipping (1 hour)
c. Using SMCP in internal communications (7 hours)
d. Using SMCP in external communications (6 hours)
These specific topics for internal and external communication will vary by program (Marine Engineering and Marine Transportation). 